\title{
A Review on Temperature Control of Proton Exchange Membrane Fuel Cells
}

\author{
Qinghe Li ${ }^{1}$, Zhiqiang Liu ${ }^{1}$, Yi Sun ${ }^{2}$, Sheng Yang ${ }^{1, *}$ (1) and Chengwei Deng ${ }^{2, *}$ \\ 1 School of Energy Science and Engineering, Central South University, Changsha 410083, China; \\ lqingh@csu.edu.cn (Q.L.); liuzq@csu.edu.cn (Z.L.) \\ 2 Space Power Technology State Key Laboratory, Shanghai Institute of Space Power-Sources, \\ Shanghai 200245, China; sunyi082032@163.com \\ * Correspondence: ceshyang@csu.edu.cn (S.Y.); dengchengwei@spacechina.com (C.D.)
}

Citation: Li, Q.; Liu, Z.; Sun, Y.; Yang, S.; Deng, C. A Review on Temperature Control of Proton Exchange Membrane Fuel Cells. Processes 2021, 9, 235. https:// doi.org/10.3390/pr9020235

Academic Editor: Alfredo Iranzo Received: 29 December 2020

Accepted: 24 January 2021

Published: 27 January 2021

Publisher's Note: MDPI stays neutral with regard to jurisdictional claims in published maps and institutional affiliations.

Copyright: (c) 2021 by the authors. Licensee MDPI, Basel, Switzerland. This article is an open access article distributed under the terms and conditions of the Creative Commons Attribution (CC BY) license (https:// creativecommons.org/licenses/by/ $4.0 /)$.

\begin{abstract}
This paper provides a comprehensive review of the temperature control in proton exchange membrane fuel cells. Proton exchange membrane (PEM) fuel cells inevitably emit a certain amount of heat while generating electricity, and the fuel cell can only exert its best performance in the appropriate temperature range. At the same time, the heat generated cannot spontaneously keep its temperature uniform and stable, and temperature control is required. This part of thermal energy can be classified into two groups. On the one hand, the reaction heat is affected by the reaction process; on the other hand, due to the impedance of the battery itself to the current, the ohmic polarization loss is caused to the battery. The thermal effect of current generates Joule heat, which is manifested by an increase in temperature and a decrease in battery performance. Therefore, it is necessary to design and optimize the battery material structure to improve battery performance and adopt a suitable cooling system for heat dissipation. To make the PEM fuel cell (PEMFC) universal, some extreme situations need to be considered, and a cold start of the battery is included in the analysis. In this paper, the previous studies related to three important aspects of temperature control in proton exchange membrane fuel cells have been reviewed and analyzed to better guide thermal management of the proton exchange membrane fuel cell (PEMFC).
\end{abstract}

Keywords: proton exchange membrane fuel cell; temperature control; cold start; temperature distribution; cooling system

\section{Introduction}

As a kind of high efficiency and environmental protection energy device, fuel cells have been highly expected and have a broad application prospect. In particular, as the problems of environmental pollution and the energy crisis are becoming more and more serious, green renewable energy has become an urgent demand in today's society. Because fuel cells are highly efficient and environmentally-friendly green-energy technologies, they have developed very rapidly. To date, there are many types of fuel cells, including proton exchange membrane (PEM), solid oxide (SO), alkaline, direct methanol (DM), phosphoric acid (PC), and molten carbonate (MC) fuel cells, each has its own advantages. As a current research hotspot, proton exchange membrane fuel cells do not involve the combustion process of hydrogen and oxygen during power generation, so they are not limited by the Carnot cycle and have a high energy conversion rate. In addition, the proton exchange membrane fuel cell does not produce pollution during power generation. The system unit is modular, with high reliability, and is easy to assemble and maintain. Compared with traditional power generation devices, it does not produce noise; the working temperature is lower; the startup response faster, etc. [1,2]. These advantages make it stand out among many fuel cells. In recent years, PEM fuel cells (PEMFCs) have developed very rapidly and have made tremendous progress and breakthroughs. They have been successfully applied in some fields, such as portable power supplies, transportation, and 
aerospace equipment [3]. Despite this, there are still some technical barriers that restrict its commercial application.

The PEMFC generates electricity and releases heat simultaneously in the electrochemical reaction process. The local and overall current density distribution of the stack is closely related to the temperature distribution. The current density related to the reactant supply strategy directly affects the temperature distribution inside the stack, and the temperature affects the stack performance by controlling the electrochemical reaction rate. In addition to relying on the stack, the stable operation of the fuel cell system requires a corresponding subsystem to form a balance of plant, which mainly includes: Oxidant subsystem, fuel subsystem, cooling subsystem, electrical subsystem, and control subsystem. For the temperature control of fuel cells, the cooling subsystem is critical. Generally, the hydrogen energy utilization of PEMFCs is shown in Figure 1. In addition to the generated electrical energy, the heat generated is also considerable, which is equivalent to $45 \%$ to $60 \%$ of the total hydrogen energy entering the battery [4]. However, the exhaust temperature of the fuel cell is relatively low (including the evaporative heat absorption of the product water, this part of the energy is affected to a certain extent by the temperature of the operating point), the heat taken away by the exhaust is only about $3 \%$, and the proportion of radiation heat dissipation and natural convection of air is very small. Most of the heat needs to be taken away by an additional cooling system. Itis necessary to carry out temperature control and optimized design of the cooling subsystem for the proton exchange membrane fuel cell to ensure the efficient and stable operation of the fuel cell [5]. PEMFC thermal management can be divided into two processes: Temperature control and heat recovery. The humidity of the proton exchange membrane is more sensitive to temperature. Too high or too low temperature and humidity have a direct impact on the performance of the membrane and stack. A reasonable choice of a cooling system is required. On the basis of ensuring the efficient and stable operation of the stack, the excess waste heat is removed, and at the same time, the temperature distribution is uniform and stable. Heat recovery is based on the control of the entire stack of waste heat recovery and reuse. Depending on the application, the stack can use waste heat cooling, heating, or power generation to improve energy efficiency and reduce energy consumption.

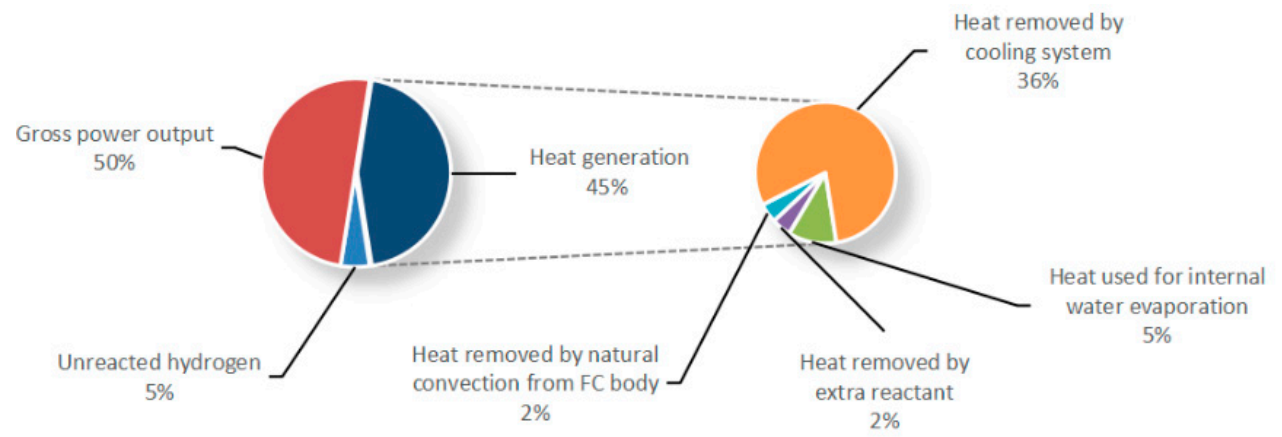

Figure 1. Distribution diagram of hydrogen energy utilization [6]. Reproduced with permission from Shabani, B. and Andrews, J. An experimental investigation of a PEMFC to supply both heat and power in a solar-hydrogen RAPS system; published by International journal of hydrogen energy, 2011.

As the reaction progresses in the fuel cell, heat is generated. This part of thermal energy and electrical energy are of the same order of magnitude. Ensuring that the fuel cell temperature is kept at an ideal level is an important goal of fuel cell design, so it is necessary to adopt appropriate management strategies to control the temperature to avoid fuel cell overheating or high-temperature gradient. Higher temperature will speed up the electrochemical reaction rate [7]. In general, for a regular structure PEMFC stack, the highest temperature is located in the center of the stack. Higher temperatures tend to cause membrane dehydration to dry and voltage sag. If the local current density is too high, hot spots will also be generated. The reaction gas supplied by the cathode is compressed air, which greatly increases the temperature of the air and has a certain adverse effect on 
the stack. In severe cases, the membrane may be damaged [8]. When the temperature is too high, the membrane will be dehydrated and dry, causing irreversible losses; low temperature may cause flooding of the cathode flow channel, which makes oxygen unable to pass through the gas diffusion layer. In addition, the diffusion rate of oxygen itself is low, and the concentration overpotential increases rapidly, reducing the stack output performance. When the temperature distribution is uneven, the electrochemical reaction rate in the local area is accelerated, resulting in product accumulation affecting the overall performance of the battery [9]. When selecting the cooling method, it generally depends on the power of the fuel cell. Small fuel cells (i.e., $<2 \mathrm{kw}$ ) often adopt air cooling. The liquid cooling strategy can emit more heat at the same level of parasitic power, and it has been widely used in high power (i.e., $>5 \mathrm{kw}$ ) fuel cell stacks [10,11]. Within the range of $2 \sim 5 \mathrm{kw}$, it can be selected according to demand. For fuel cells, air cooling and liquid cooling have their own advantages and features, as shown in Table 1.

Table 1. Air cooling and liquid cooling [12]. Reproduced with permission from Ramezanizadeh, M. et al., A review on the approaches applied for cooling fuel cells; published by International Journal of Heat and Mass Transfer, 2019.

\begin{tabular}{ccccc}
\hline Cooling Method & Application Power Range & System Complexity & Difficulty in Maintaining Temperature Uniformity & Cooling Channel \\
\hline Air-cooling & $<2 \mathrm{kw}$ & Lower & Higher & Higher \\
Liquid-cooling & $>5 \mathrm{kw}$ & Higher & Lower & Lower \\
\hline
\end{tabular}

In addition to the use of cooling and heat dissipation for thermal control of the stack, the use of high thermal conductivity materials and reasonable structural design is also an important means to evenly distribute the stack temperature. A low-temperature cold start is also an important aspect in the field of fuel cell temperature control. Auxiliary equipment or strategy is used to preheat the stack to help it realize a low-temperature cold start, making PEMFCs more universal and stable operation in extreme cases. This paper focuses on the comprehensive review of the above aspects, summarizes and analyzes the existing research results, and provides guidance for subsequent research.

\section{Research on Temperature Characteristics}

The operation of PEMFCs involves many physical and chemical processes, such as energy conversion, heat transfer, and component transportation. The heat generated by the internal electrochemical reaction can heat itself. It involves the phase transition of water, convection heat exchange between external air, and internal air to the PEMFC. It cannot spontaneously make the temperature distribution of the membrane, electrode nor the entire stack uniform and stable. This results in the temperature difference between the monolithic membrane electrode and the membrane electrode [13]. Therefore, it is necessary to understand the heat transfer characteristics inside the fuel cell before temperature control. First, for an independent stack, heat generation begins with an electrochemical reaction. According to the law of conservation of energy, the total energy produced by the electrochemical reaction should be the sum of the heat generated and the electrical power:

$$
\frac{1}{2 F} H n=Q+I V n
$$

where $H$ is the enthalpy change of the electrochemical reaction, which depends on the state of the product; $F$ is the Faraday constant; $n$ is the number of single cells in the stack; $Q$ is the thermal power generated by the stack. This is only an approximate description, because it does not include the enthalpy and heat carried away by the product and the fuel that will be reacted in the future. A more accurate description of the conservation of fuel cell energy should be:

$$
\sum\left(h_{i}\right)_{\text {in }}=W_{\text {ele }}+\sum\left(h_{i}\right)_{\text {out }}+Q
$$

For the overall fuel cell stack, the enthalpy of the reactant input to the stack should be equal to the sum of the generated electrical energy, the enthalpy of the components leaving 
the stack, and the heat generated. This part of the heat is the reaction heat, but this is not all the heat generated by the stack. Due to the thermal effect of the current, some heat will also be generated. This also affects the overall temperature change of the stack.

In the follow-up process, there are three main heat transfer methods: Heat conduction between solid phases, convection between gas-liquid two phases and solid walls, and phase change heat absorption of water in the fluid. Understanding the internal temperature characteristics of the PEMFC stack is helpful for temperature control. Currently, there are two methods of simulation and experimentation. The simulation method generally uses a non-isothermal model for the numerical calculation to understand and predict the actual situation inside the PEMFC [14]. Some researchers [15-17] have established a 3D numerical thermal model to predict the temperature distribution by solving the conservation equation in the entire cathode flow channel. The results show that the air flow rate and the thermal conductivity of the bipolar plates are the key factors that affect the temperature distribution of the battery. The use of appropriate cooling strategies or plate materials can reduce the temperature gradient in the fuel cell. In addition, for the measurement of the internal temperature of the fuel cell stack [18-20]. The accepted method is to use in-line thermocouples for in-situ temperature measurement with the aid of a thermal imager to analyze the temperature characteristics of the stack. It should be noted that the method of using embedded thermocouples will also affect the stack to a certain extent. In order to improve the accuracy of temperature testing, many different optimization measures were taken appropriately. Lee et al. [21] used microelectromechanical system technology to integrate the temperature sensor into a $40 \mu \mathrm{m}$ thick stainless-steel substrate. A temperature and electrochemically resistant polyimide is used as a protective layer, which has an impact on the performance of PEMFC stacks of less than 1\%. Adopted the micro-electromechanical systems (MENS) technology can measure temperature, voltage, and electric current at the same time; its sensor design drawing is shown as in Figure 2. As of now, the thermoelectric lotus sensor is made as thin as $25 \mu \mathrm{m}$ [22], achieving a rapid response to temperature. Kristopher et al. [23] adopted an optical temperature measurement method, which contained the temperature measurement error within $\pm 0.6{ }^{\circ} \mathrm{C}$. The temperature test method for high-temperature proton exchange membrane fuel cells is similar, and there is no significant difference. Siegel et al. [24] adopted a segmented temperature measurement method to study the influence of fluid on the temperature of the solid phase. At the same time, according to different operating conditions, such as no-load and load, corresponding discussions were also conducted. Under no-load conditions, the temperature distribution in the battery is strongly related to the flow field structure and gas flow rate. Compared with the flow-field with 26 channels parallel straight and combined mixed serpentine, increasing the air flow rate has a greater impact on the solid phase temperature distribution of flow-field with six channel parallel serpentine. Under load conditions, the temperature distribution is mainly affected by the current density.

The precise measurement of the temperature of the fuel cell stack helps to optimize the uniformity of the temperature distribution, and the optimized design of the material structure helps to make the temperature distribution uniform. The main purpose is to use the superior thermal conductivity of the conductive materials and the optimization of the heat dissipation of the structure to avoid local high temperature simultaneously, the reactant is evenly distributed through the optimized design of the flow channel structure. As mentioned in the previous section, due to the thermal effect of the current, in addition to the reaction heat, other parts of the heat will be generated to affect the temperature of the fuel cell. Compared with the inevitable heat of reaction, this part of heat can be optimized through the design of the fuel cell assembly material structure. Chi et al. [25] studied the relationship between membrane thickness and temperature distribution by establishing a non-isothermal two-dimensional (2-D) aggregate model. The simulation results fit well with the experimental data. The results show that the membrane thickness is positively correlated with the battery temperature, and due to the low thermal conductivity of the 
membrane, the increase in thickness is not conducive to the transfer of heat, but it increases the internal impedance of the battery, resulting in excessive local temperature.

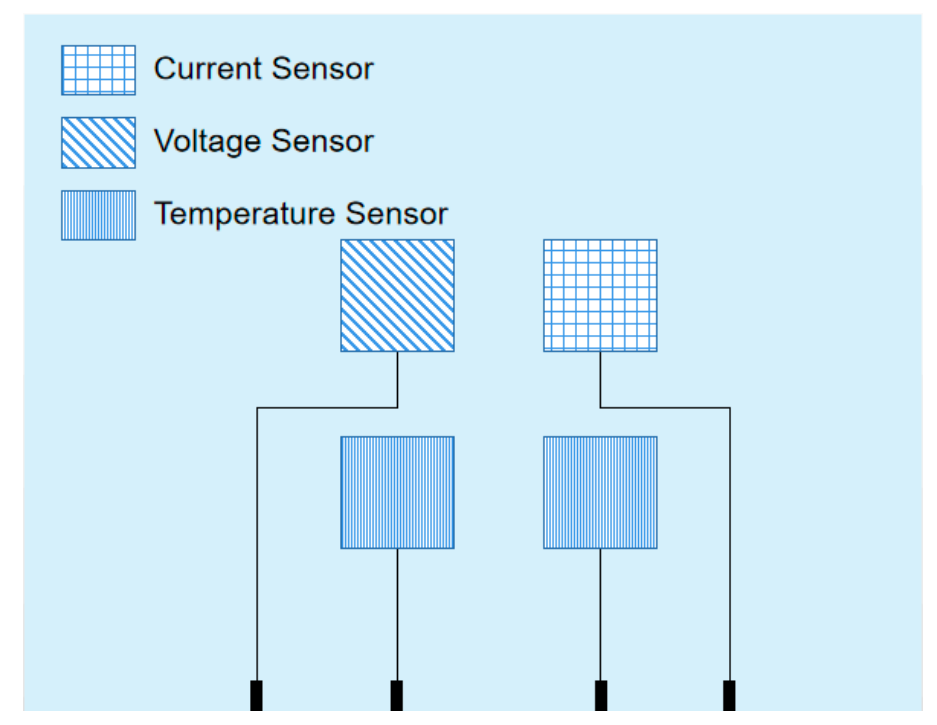

Figure 2. Design diagram of temperature, voltage, and current sensors [21]. Reproduced with permission from Lee, C.-Y. et al., Flexible micro temperature, voltage and current sensors for local real-time microscopic diagnosis inside high temperature proton exchange membrane fuel cell stack; published by Renewable energy, 2017.

\section{Temperature Control Based on Battery Material Structure}

\subsection{Material-Based}

Bipolar plates (BPP), gas diffusion layer (GDL), catalytic layer (CL), and proton exchange membrane are the basic components of PEMFCs. The structure of the single cell is compact, mainly composed of the bipolar plate of the cathode and anode and the membrane electrode assembly in the middle. Among them, the conductivity of the bipolar plate and the gas diffusion layer and the contact resistance between them affect the battery performance. This part of the impedance is the main source of ohmic polarization loss. Especially the contact resistance between the bipolar plate and the gas diffusion layer, causing ohmic polarization loss to account for $10 \%$ of the total $[26,27]$. The ohmic polarization loss of the PEMFC is manifested as the decrease of the external output voltage. On the other hand, it shows an increase in its own heat. The optimization design based on the battery material can reduce the overall temperature of the battery, reduce the unnecessary energy loss and improve the battery performance.

\subsubsection{Bipolar Plates}

The bipolar plate provides a gas flow path to prevent the hydrogen and oxygen in the battery gas chamber from communicating with each other, and to establish a current path between the cathode and anode in series to manage the heat dissipation of the entire battery. Its material properties have a greater impact. At present, there are three types of bipolar plate materials for PEMFCs: Graphite, metal, and composite materials. The performance comparison of the three materials is shown below in Table 2. Compared with the other two material bipolar plates, the graphite bipolar plate performs poorly in terms of mechanical strength and production processing. It also does not have an advantage in weight and volume. Pyrolytic graphite sheets $[28,29]$ are less massive and have higher thermal conductivity. Some researchers have used them as polar plate materials for experiments, and embedded thermocouples have been used for temperature testing. These experiments have effectively homogenized the temperature inside the battery and to a certain extent. The ionic conductivity of the membrane electrolyte is improved. Although graphite bipolar plates perform well in certain properties, due to their own attributes and 
limitations in production and processing, metal bipolar plates and composite bipolar plates have become popular choices.

Table 2. Performance comparison of three bipolar plate materials.

\begin{tabular}{cccc}
\hline Property & Graphite Bipolar Plate & Metal Bipolar Plates & Composite Bipolar Plate \\
\hline mechanical strength & Low & High & High \\
Conductive intensity & High & High & Medium \\
thermal diffusivity & High & Medium & Low \\
Chemical stability (corrosion resistance) & High & Low & High \\
volume & High & Medium & Low \\
weight & High & High & Low \\
processing difficulty & High & Low & High \\
production cycle & High & High & \\
\hline
\end{tabular}

The metal bipolar plate has higher mechanical strength and electrical conductivity. However, since an oxide layer that increases resistivity can be formed on the metal surface, contact resistance increases with the growth of the oxidized interface [30,31], and unnecessary heat generation reduces the efficiency of the fuel cell. Therefore, increasing the corrosion resistance of metal bipolar plates is a key issue in the research of metal bipolar plates. Metal materials, such as stainless-steel [32-34] (SS), titanium [35,36] (Ti)are favored because of their superior conductivity, corrosion resistance, and relatively low cost have been selected as the base material of plates in many studies. In order to maintain the electrochemical stability of the bipolar plate and further improve its performance, the method of coating protection is generally adopted $[37,38]$. At present, a variety of coating protection materials have been developed. Some researchers [39-42] prepared TiN nanometer-thin films by plasma-enhanced atom deposition, which reduced the contact pressure at the interface of stainless-steel by approximately half. Similarly, there are $\mathrm{CrN} / \mathrm{Cr}$ multilayer coatings $[43,44]$

$\mathrm{Al}_{2} \mathrm{O}_{3} / \mathrm{TiO}_{2}$ nanometer amine film [45,46], carbon coating [47], TaN/Ta multilayer coating [48,49], Nickel-based nanocrystalline and amorphous alloy coating [50], etc.

Composite material bipolar plates can be prepared by adding suitable conductive materials to polymer materials based on thermosetting or thermoplastic [51,52]. The composite bipolar plate is compatible with the corrosion resistance and high strength characteristics of graphite bipolar plate and metal bipolar plate, respectively, so there is no need for coating protection like metal material, and the production efficiency is high. Generally, it only needs to be prepared once. Low conductivity is the main factor restricting its development, which will seriously affect cell efficiency. High conductivity filler is generally added to the bipolar plate, which can optimize the overall resistivity [53,54]. Researchers $[55,56]$ have embedded high conductivity particles into carbon fiber composite bipolar plates to reduce their overall resistivity. Zulfia et al. [57] performed material optimization to design the polymer and the carbon composite material, quantitatively studied the corresponding conductive particle influence on the conductivity. The conductive filler used at present mainly consists of multi-wall carbon nanotubes [57], graphite [58,59], carbon nanotubes, or graphene [60,61], etc.

\subsubsection{Gas Diffusion Layer}

The diffusion layer plays a role in supporting the membrane electrode assembly in the PEMFC, transporting reactants and products, and conducting electricity and heat. At present, it is considered as a solid material with constant resistivity in most studies, and resistance is sometimes ignored [62,63]. In fact, the thermal conductivity of the diffusion layer, the volume resistance, and the contact resistance with the bipolar plate are not only affected by the structure of the material itself, but also by the mechanical load during the battery preparation process, which has a set influence on the properties of the material and its microstructure [64,65]. Qiu et al. [66] studied the conductivity and thermal conductivity 
of GDL under cyclic and stable loads and the variation of its microstructure. It should be noted that although compressing GDL can improve its conductivity, it must be controlled within a certain range [67], otherwise it will be counterproductive. The relatively low thermal conductivity of the fuel cell microporous layer tends to lead to high GDL temperature [68], where the product water can undergo a phase transition. Researchers [69-71] uses fluorescence microscope, optical photography, synchronous x-ray, and other equipment to study the microstructure and transmission of the GDL. When the filler is increased within a certain range, the thermal conductivity of the GDL can be increased.

\subsubsection{Proton Exchange Membrane}

The proton exchange membrane is a key component of the PEMFC. Generally speaking, the ohmic heat is affected by the thickness of the membrane and the conductivity of the material. Two methods [72,73] have been widely accepted to solve this problem. One is to reduce the amount of perfluororesin and to prepare composite membranes by combining Nafion resin with other non-fluorinated materials; the other is to develop new membrane materials. The proton exchange membranes currently used in PEMFCs can be mainly divided into three types: Perfluorinated PEM, partially fluorinated PEM, and nonfluorinated PEM. The perfluorinated PEM [74,75] is a perfluorosulfonic acid membrane, which has good proton conductivity, but it strongly depends on its degree of hydration. The perfluorosulfonic acid membrane has low water content or high temperature without water supplement. Under the circumstances, the conductivity will drop significantly. Some researchers [76-78] modified the perfluorosulfonic acid membrane to reduce the amount of perfluororesin, while ensuring proton conductivity, and correspondingly reduce the thickness of the membrane. Similar partially fluorinated PEM [79,80] and non-fluorinated PEM [81-84] have also optimized their own electrochemical impedance; at the same time, it also improves the service life of the PEM and reduces the production cost.

\subsection{Structure-Based}

\subsubsection{Channel Structure of Reactants}

The concentration of reactants in PEMFC stack directly affects the electrochemical reaction rate [85-87] and indirectly controls the current density and temperature distribution uniformity. The concentration distribution of reactants with the same mass flow rate is controlled by the effective surface area of the channel structure, Li et al. [88,89] established a three-dimensional non-isothermal model. By comparing the DC flow path with the serpentine flow path, it is found that the serpentine flow path performs better in the uniformity of the reactant distribution and the temperature distribution. Debanand et al. [90] optimizes the serpentine flow field and designs a novel flow field structure based on retaining some of the flow field characteristics. Compared with the traditional serpentine channel, it can provide a more uniform current density distribution. Li et al. [91] establish a three-dimensional non-isothermal steady-state model to study the stack performance and mass transfer characteristics of PEMFCs using metal foam as the reactant flow distributor. At the same level of working voltage, the current density can be increased by about $5 \%$. In the traditional channel structure design, due to the existence of rib, the reactant concentration in the rib covered area is relatively low, because of the limited diffusion effect. The uniform distribution of the metal foam flow field can evenly distribute the reaction fluid and improve the uniformity of reactants, current density, and temperature in the stack. Some researchers [92,93] compared the performance of traditional flow channel, flow channel with spoiler and metal foam flow channel. The use of spoiler and metal foam increased the axial diffusion strength of the reaction gas. The oxygen concentration on the gas diffusion layer increased significantly, and the current density and temperature uniformity improved significantly compared with the straight channel. The reactants in the metal foam flow channel are more evenly distributed and not affected by porosity compared to if the spoiler block is added. Similarly, there are porous metal bipolar plates [94]. It is 
also possible to optimize the battery performance by changing the structure, but not the material, to improve the temperature uniformity.

\subsubsection{Cooling Channel Structure}

The internal temperature distribution of PEMFCs is largely influenced by the internal fluid flow characteristics. As the cooling process progresses, the refrigerant cooling performance decreases along the cooling channels. Some researchers [95] designs for cooling channels possess a non-uniform cooling pipe with different cross-sectional areas to improve the cooling capacity downstream of the cooling channels. Ebrahim et al. [96] conducted a comparative study of the "Zigzag" cooling flow channel and the straight channel, which decreased $5 \%, 23 \%$, and $8 \%$ in terms of maximum surface temperature, surface temperature difference, and temperature uniformity index, respectively. In addition, the study of the fuel cell flow field [97-99] found that the maximum temperature and temperature uniformity were used as the evaluation criteria. The traditional serpentine channel is better than the straight channel, and the multi-channel serpentine channel is better than the traditional serpentine channel. In the subsequent quantitative research, it was found that the cooling effect and overall uniformity could be further improved by adjusting the coolant flow along the parallel path and the distribution strategy. It can be seen that although the complexity of the cooling flow channel structure is appropriately increased and the temperature distribution of the stack is improved to a certain extent, the pressure drop of the cooling flow channel is correspondingly increased, and new requirements are put forward for the performance of pump and valve. The appearance of the metal foam multi-media flow field supplements this $[10,100]$. Due to its higher permeability coefficient, the oxygen concentration and current density of the cathode catalyst surface are increased, and the coolant pressure drop is relatively low, which can more effectively distribute the cooling medium.

\section{Temperature Control Based on Cooling Medium}

The uniformity of temperature distribution of a fuel cell has a great influence on its life and performance. Some researchers measured the temperature difference between the inlet and outlet of the cooling channel as high as $23^{\circ} \mathrm{C}$ through simulation and experiment, and the temperature difference between the channels was more than $10^{\circ} \mathrm{C}$. The general way to improve the internal temperature distribution uniformity was to reduce the temperature difference between the inlet and outlet of the cooling medium by adjusting the coolant flow rate [17,101-103]. The waste heat removal mode of a fuel cell is mainly related to its power. According to the involved cooling medium, the cooling mode is divided into heat dissipation based on gas medium and heat dissipation based on the liquid medium. As shown in Figure 3, heat dissipation based on gas medium mainly includes: Cathode air cooling, separated air cooling, and edge cooling; heat dissipation based on the liquid cooling medium includes liquid cooling and phase change cooling. Figure 4 shows the cooling technology for the heat dissipation of PEMFCs. It can be seen that in addition to the cathode gas cooling, the other four cooling methods are arranged between the single cells of the PEMFC stack. The density of the layout cooling system is not only limited by cooling requirements, but also by battery power output, volume, and weight.

\subsection{Heat Dissipation of Gas Cooling Medium}

The balance of plant required for temperature control of the stack by air cooling is extremely small, and only the ambient air needs to pass through the heat dissipation plate of the cathode side of the stack, or between the electrodes. The focus is on the air supply strategy of the cooling medium and the stack structural optimization and system design. This heat dissipation method is generally designed for small stacks. Air cooling systems typically include equipment or structures, such as fans/blowers, temperature sensors, cooling channels, etc. The selection of fans is critical and is generally based on the mass flow and volume pressure drop of the fuel cell system operating at maximum power. 


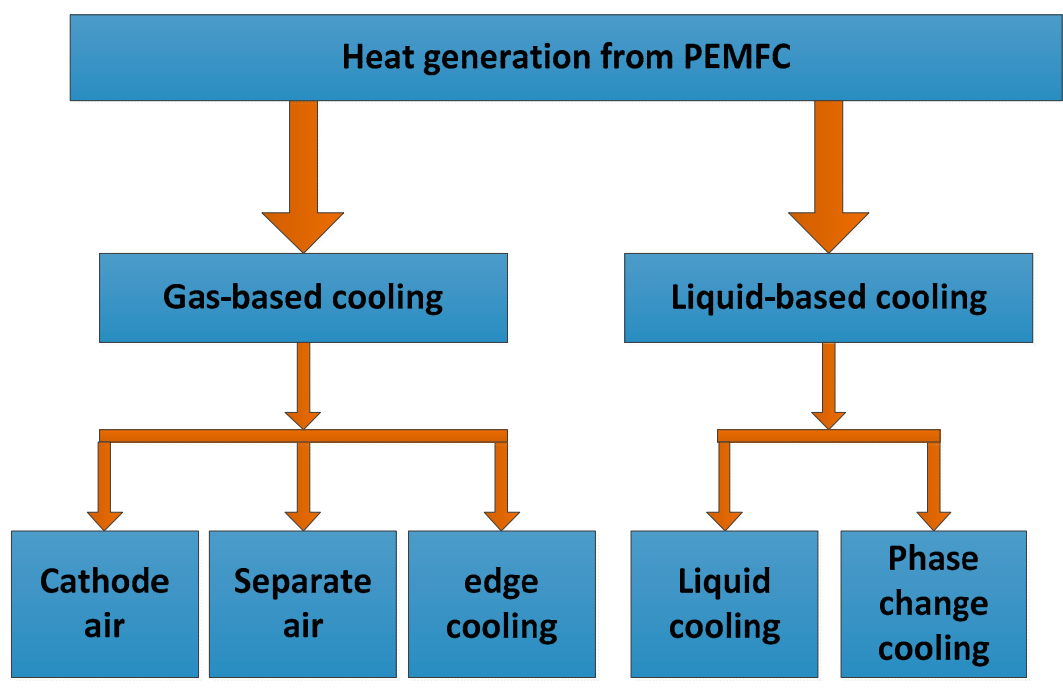

Figure 3. PEMFC cooling method [4]. Reproduced with permission from Nguyen, H.C. and Shabani, B., Proton exchange membrane fuel cells heat recovery opportunities for combined heating/cooling and power applications; published by Energy Conversion and Management, 2020.

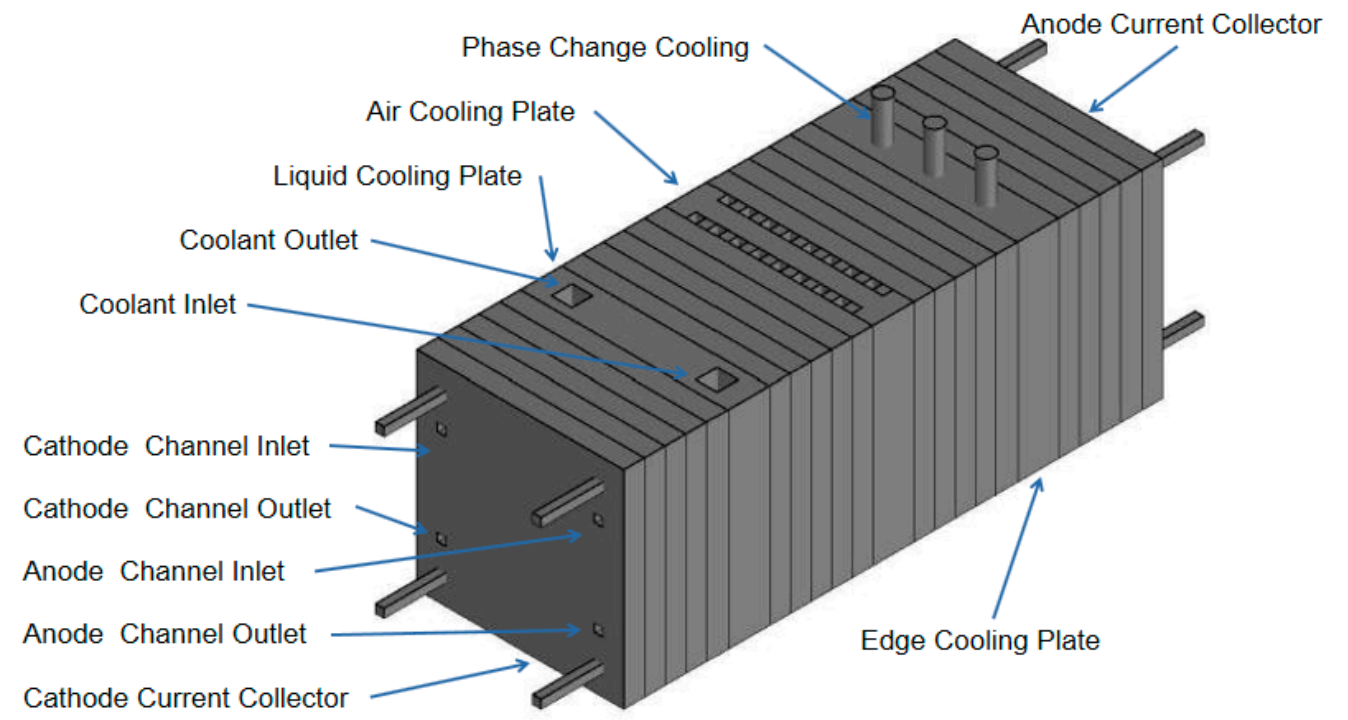

Figure 4. Demonstration of cooling methods for proton exchange membrane fuel cells (PEMFCs). [10]. Reproduced with permission from Hossain, M.S. and Shabani, B., Metal foams application to enhance the cooling of open cathode polymer electrolyte membrane fuel cells; published by Journal of power sources, 2015.

\subsubsection{Edge Cooling}

Edge cooling is a passive cooling technology that relies on air convection to cool PEMFC stacks. Because there is no cooling channel inside the stack of fuel cells that use edge cooling, they are more compact in structure and have certain volume advantages. In the choice of materials, high thermal conductivity materials are often used to quickly conduct internal heat to the surface of the stack. The surface is often designed to enhance heat dissipation. This cooling method has limited heat dissipation effects and is generally used in portable and other low-power equipment. The main methods of temperature control using edge cooling are [104]: (i) Use appropriate high thermal conductivity materials to discharge the internal temperature of the stack as soon as possible to reduce the temperature difference between the inside and outside of the stack; (ii) optimize the design of the external structure of the stack to obtain a sufficiently high heat dissipation rate. Choosing 
high thermal conductivity fin material can provide a higher heat transfer rate [105]. The choice of fins is mostly graphite-based materials, such as expanded graphite, pyrolytic graphite, etc. [28,29]. In addition, the fin geometry design also affects the heat transfer rate and stack performance. Compared with fin thickness, the effect of fin length on battery performance is more significant. At the same time, the relatively dense arrangement of fins in a suitable interval is also conducive to heat dissipation of the stack and increases battery performance [106]. Some researchers [107] studied the heat dissipation performance of rectangular and triangular fins (the total area of the two fins is the same). The results show that the heat dissipation effect of the fuel cell with fin structure is more significant, and the temperature distribution of the whole battery is more uniform. In addition, compared with rectangular fins, the use of triangular fins can achieve higher power density.

\subsubsection{Cathode Air}

The cathode air cooling method combines the cathode and cooling channels [108]. The incoming air acts as an oxidant to participate in the electrochemical reaction and also as a coolant. It dissipates heat from the system, so no additional cooling channels are required, and the stack structure is relatively simple. Kai et al. [17] has developed a fuzzy controller with multiple inputs and multiple outputs to maintain the temperature of the PEMFC stable within a certain range through fuzzy control of the fan speed. Da et al. [103] adopts the method of adjusting the air flow and temperature, which increases the current density of the stack, reduces the overall size of the stack, and reduces the complexity of the system while improving performance. However, this method also drastically increases the parasitic power of the blower [109], and the specific economy needs to be considered. The temperature control of the battery using cathode air cooling is usually achieved by adjusting the air flow rate $[110,111]$. When the cooling flow required by the system is high, the stoichiometric ratio of air will be relatively high, but this may reduce the humidity of the membrane, resulting in fuel cell performance is reduced, and it is difficult to achieve precise temperature control $[112,113]$. This is a drawback of cathode air cooling.

\subsubsection{Separate Air}

Separate air cooling separates the cathode flow channel from the cooling flow channel, which can separately supply the oxidant and control the temperature of the stack. Dicks et al. [2] researched the system and designed a separate cooling channel, using fans or blowers as circulating power. The results show that although the system is complex, the temperature is relatively controllable. When the fan or blower is used as the circulating power of the cooling system, additional parasitic power will be generated [85]. By adjusting the width of the cooling channel, this situation can be effectively improved. Research shows that increasing the effective cooling area of the cooling channel can achieve a more uniform temperature distribution. Wei et al. [114] proposed the finite state machine control and the air flow speed control strategy based on the conventional proportional-integral control to adjust the direction of the coolant air flow. When the experiment is performed on the $1.2 \mathrm{kw}$ PEMFC, it can enhance certain battery performance and reduce the temperature within a $0.5^{\circ} \mathrm{C}$ gradient. Cheng et al. [115] add a model controller with nonlinear feedforward and $\mathrm{LQR}$ state feedback to the air-cooled heat dissipation system to control the fan speed and maintain the stack temperature within $\pm 0.5^{\circ} \mathrm{C}$.

\subsection{Liquid Cooling Medium Heat Dissipation}

Liquid media has a higher heat capacity than gas media and is often used to cool large stacks. When the power of the stack is higher, and the heat dissipation requirements are greater, the use of liquid cooling often has a better heat dissipation effect. Temperature control using liquid cooling is usually done by adjusting cooling channels, optimizing coolant selection, controlling mass flow, and other methods. The liquid cooling medium heat dissipation system [10] is mainly composed of pumps, cooling pipes, and condensers. The pump is the circulating power of the cooling system, which helps the coolant to collect 
and release heat, but it is not indispensable. For example, in a closed-loop passive cooling system [116], only the phase change of the liquid cooling medium can complete the entire heat dissipation process; The cooling flow channel is the carrier of the cooling liquid. The layout of the cooling flow field has a great influence on the temperature distribution inside the stack. Compared with the cooling system using a gas medium, the layout is more complex. It is mainly responsible for carrying the cooling liquid to complete the entire cyclic process; the coolant is a carrier of heat. It absorbs heat in the stack to reduce the temperature of the stack. The coolant that carrys the heat releases the heat in the condenser and re-enters the stack to complete the entire cooling cycle.

\subsubsection{Liquid Cooling}

Water, as a commonly used liquid cooling medium, is not irreplaceable. When the normal heat dissipation requirements of the system cannot be met, or the heat dissipation requirements can be met, but the area of the heat sink needs to be increased as compensation, materials with better heat dissipation performance can be considered. In general, metallic liquids tend to have better thermal conductivity than nonmetallic liquids. Considering the operating temperature range of the PEMFC and the economy of the PEMFC system, the use of metal liquids is too costly. The method of using conventional fluids to carry metal particles is considered. The more promising way is to add nano-scale metal or non-metal particles to the basic fluid to form a nanofluid [117-121], such as nanoparticles with small size and large specific surface area, can significantly improve the heat transfer coefficient and viscosity coefficient of the nanofluid, and can stand for a long time without settlement, which will not cause the blockage of the cooling pipeline. This is an advantage that large particles, small particles, and even microscopic particles do not have. A study found that as the concentration of nanoparticles increases, the thermal conductivity also increases [122]. Additionally, when the temperature goes up, the thermal conductivity goes up. Mohammad et al. [123] added nanometer solid particles of aluminum oxide in water as a nanofluidic cooling medium to dissipate heat for a $2.4 \mathrm{kw}$ fuel cell. A semi-analytical steady-state model was used to consider its cooling performance. Zakaria et al. $[124,125]$ uses $\mathrm{SiO}_{2}$ and $\mathrm{TiO}_{2}$ nanofluids to study the effect of concentration on heat dissipation performance. While the cooling effect is improved, the external power input is increased, due to the viscosity effect. Therefore, the overall energy efficiency level of the system needs to be considered comprehensively. The liquid cooling medium has a certain conductivity compared to the gas cooling medium $[118,126,127]$. In order to prevent current leakage, a deionization device is usually added to the cooling circuit, which is also an important reason why its system complexity and maintenance cost are higher than that of the air-cooling system.

\subsubsection{Phase Change Cooling}

As a special form of heat dissipation using a liquid medium, phase change cooling is also applied to the field of fuel cell temperature control. Compared with other heat dissipation methods, it has higher latent heat. Occasionally, no additional circulation power is required, and the entire cooling cycle system can be completed only by hydrophilic wicking or density difference [1]. The study found that under the same working conditions [128], the size of the radiator using phase change cooling can be reduced by about $27 \%$ compared with the liquid cooling radiator, and a more uniform temperature distribution can be obtained [129]. Compared with metal heat conduction, the phase change cooling effect is better [130-132].

A heat pipe is widely used in high temperature fuel cells, such as solid oxide fuel cells, due to its good heat dissipation effect. In addition, because of its good heat-carrying capacity, waste heat is often recovered at the end of the system cycle to improve the energy efficiency of the system level. Without a doubt, there are also applications in the field of PEMFCs. In response to the heat dissipation requirements of PEMFCs, Jason et al. [116] have proposed a pulsating heat pipe that uses closed-loop passive heat dissipation to rely on the phase change of the cooling medium to complete the entire cycle of heat dissipation, 
without adding ancillary cooling equipment. Marcos et al. [104] uses a small flat heat pipe that retains only the evaporator and condenser to dissipate heat from the PEMFC, and uses deionized water as a medium. Through experimental and theoretical analysis, it is found that its heat transfer ability is strong, up to $1.8 \mathrm{~W} / \mathrm{cm}^{2}$. Navid et al. [132] applied micro heat pipes to the cooling of PEMFCs. The ends used natural convection, forced air convection, and water for heat dissipation. The best heat dissipation mode for water was determined.

Phase change cooling using liquid medium includes evaporation cooling in addition to heat dissipation of heat pipe. Evaporative cooling adds liquid water to the cathode flow channel of the PEMFC, where it undergoes phase change evaporation, which can both achieve heat dissipation and humidification of the stack, and then the evaporated water and product water are discharged out of the stack to condense. Experiments show that $[128,133]$ the heat dissipation effect of the system using evaporative cooling is significantly higher than that of pure liquid cooling. It should also be noted that the separation efficiency of liquid water has a great influence on evaporative cooling. Schultze et al. [134] proposed a dynamic simulation model of an evaporatively cooled fuel cell stack, which can be used as a reference for model controller design. Fly et al. [135] analyzes the temperature change during the stable operation of the PEMFC stack and finds that the temperature change is within $\pm 2.0^{\circ} \mathrm{C}$. The variable working pressure and stoichiometry using proportionalintegral control can further reduce the temperature change to $\pm 1.0^{\circ} \mathrm{C}$.

\section{Cold Start}

Cold start is also an important aspect of temperature control of the fuel cell. What is different from the previous is that maintaining a uniform and stable temperature of the fuel cell often requires heat dissipation. The cold start requires the fuel cell to be preheated (i.e., warmed up). In order to make the application of fuel cells more universal, it is necessary to consider various possible situations. A low-temperature cold start is one of the technical challenges that are faced [136]. Studies have shown that fuel cells are able to start at low temperatures-they will work for a short period of time after starting, and then "turn off". This occurs because the fuel cell can normally work at low temperature, but the product, etc., condenses in the low temperature environment, blocking the intake pores, which prevents it from starting [137]. Additionally, repeated freezing will easily expand the gap and increase the internal contact resistance, due to expansion after condensation [136,138-140], which will eventually damage the components and affect the battery life. Therefore, before considering improving the cold start performance of the fuel cell, it is necessary to explore the cold start behavior and related mechanism research to improve the fuel cell operation.

Based on the thermal stability analysis method, Wei et al. [141] analyze the steadystate multiplicity behavior of PEMFCs during cold start. The advantage lies in the ability to predict various diversity behaviors and startup feasibility in a systematic and simple manner. Dursch et al. [142] used isothermal differential calorimetry to study the formation and growth of ice crystal ions at the catalytic layer of PEMFCs and the dynamic behavior of ice crystals. Sen et al. [143] proposed an analytical model to predict the cold start behavior of fuel cells based on the mechanism of water phase transition and water transfer. It was found that ice particles were preferentially formed at the junction of the microporous layer and the catalytic layer. Ko et al. [144,145] conducts research in terms of materials and develop a new type of microporous layer material by adjusting the ionomer fraction and the weight ratio of $\mathrm{Pt}$ to carbon support. This allows the transition between the microporous layer and the catalytic layer to become smooth, except for the original. In addition to the function of the microporous layer, it also has a certain proton conductivity and redox reaction kinetic activity, which expands the volume of ice storage. Some researchers [146-148] studied the hydrophobicity of the microporous layer material to improve cold start performance. From the perspective of reducing the internal water content of the PEMFC stack, Kim et al. [149] put forward a cold start strategy of pressure reduction purge to minimize the water residue. Lin et al. [150] established a three-dimensional non-isothermal multi-channel cold start 
model, using numerical simulation to study the effect of unevenly flowing reactants and coolant on the cold start performance of PEMFCs. Geonhui et al. [151] have established a transient cold start model from the start of the stack to the stable operation of the entire process. Through the prediction of each stage of cold start process and the simulation results under different cold start conditions, an effective cold start strategy is proposed.

Clamping pressure is an important parameter in the assembly of PEMFCs [152], which affects the changes in the size and physical properties of its components. Not only that, clamping pressure also has an important impact on the cold start performance of PEMFCs. Dafalla et al. [153] adjusted the three-dimensional cold start model and used numerical simulation to study the cold start behavior of PEMFCs under clamping pressure. The results show that increasing the clamping pressure will not only increase the condensation of ice in the capillary pores, but also cause dehydration and drying of the membrane. $\mathrm{Xu}$ et al. [154] built a three-axis vibration platform to study the effect of mechanical vibration direction and amplitude on the cold start performance of PEMFCs.

Hydrogenation reaction heat can be used to preheat the stack at the entrance of the stack or at the cathode flow channel $[155,156]$. Florian et al. [157] propose a method of filling methanol cells with an aqueous solution of antifreeze into the fuel cell without the need for additional waste heat equipment. Compared with methods that do not add antifreeze or purge before startup, they can ensure that the fuel cell continues to operate below zero degrees Celsius. However, this method has certain defects. When the PEMFC is operated above zero degrees Celsius, the residual antifreeze will adversely affect the temperature performance of the stack. Gwak et al. [158] improve the cold start performance of PEMFCs by optimizing the cold start strategy, proving that increasing the current density during the undersaturation phase can cause the stack to heat up quickly to prevent water condensation. In addition, once the freezing stage is reached, the current density cannot be increased; otherwise, the growth of ice crystal particles will be accelerated. Similarly, some people have integrated the parameter identification method into the semi-empirical model [159], searched for the optimal working point of the electric heap through the optimization algorithm, adopted the real-time adaptive control strategy for the current, and made the stack run at the maximum power at startup to realize the fast cold start.

The cold start real-time strategy can be collectively referred to as the internal auxiliary start strategy of the fuel cell stack, which is mainly implemented inside the fuel cell or through the optimization of its own control strategy. Conversely, for the exterior of the PEMFC, auxiliary measures can also be taken to help it achieve a cold start at low temperature. The key to ensuring a cold start of the fuel cell is to raise the overall temperature of the stack before it ends the electrochemical reaction, to prevent condensation of products, etc., blocking the intake air gap. Although the electrochemical reaction of the fuel cell generates a certain amount of heat, it is not enough to raise its temperature to a sustainable reaction stage $[160,161]$. For short-term downtime, phase-change materials are paid attention to because of their unique energy storage advantages [162], and can be used as a heat storage medium to improve cold start performance. Agus et al. [163] have proposed a new passive thermal management strategy to insulate the stack, using phase changes and insulating materials to maintain the stack temperature above the freezing point for up to two days. At present, the common way is to use the heating device to preheat the cathode plate to heat the stack [164]. Zhi et al. [165] adopt a phased preheating method, that is, from the start of the stack to the stable operation. It adopts different preheating methods to achieve gradual control and realize the cold start process. Li et al. [164] use local heating to reduce the input of auxiliary heating equipment, arranges the heating wire under the ridge of the cathode plate, maintains its continuous electrochemical reaction, and uses its own reaction heat to raise the temperature of the surrounding stack to achieve the entire stack cold start. In addition, the study found that the configuration of the electric heating wire is not as accessible. Under constant thermal power, a single heating wire shows better results than three heating wires. Zhou et al. [166] combine an external heat source with an internal load and develops a variable heat load control startup strategy to achieve a successful startup at 
$-20^{\circ} \mathrm{C}$. Although preheating the fuel cell to achieve a cold start is an effective auxiliary means, it also generates a certain amount of energy consumption and increases additional equipment costs. Therefore, cost control of auxiliary equipment is also a priority.

\section{Summary and Outlook}

The three aspects of fuel cell temperature control have been systematically listed in this paper. Proton exchange membrane fuel cells are sensitive to temperature, and they need to operate in a certain temperature range to achieve their best performance. At the same time, reducing unnecessary heat loss will improve the performance of a fuel cell, Therefore, it is necessary to adopt a reasonable control strategy for the temperature of the PEMFC.

The electrons generated by the PEMFC are transferred between the bipolar plate and the gas diffusion layer, and most of the generated heat is transferred from the gas diffusion layer to the bipolar plate in the form of heat conduction. Therefore, the bipolar plate and the gas diffusion layer itself and their electrical and thermal conductivity are particularly important. The heat transferred to the bipolar plate is transferred by the cooling system. Air-cooled medium is used for temperature control, which is generally aimed at small stacks, which can be optimized according to flow control strategy and cooling structure to improve refrigeration efficiency; the cooling of the liquid medium is mainly aimed at large stacks. Unlike pure liquid cooling, the cooling using liquid medium includes not only liquid cooling but also heat dissipation based on the liquid medium. For instance, heat pipe cooling, and evaporative cooling using liquid phase change, and nanofluid made by adding nanoparticles to the basic fluid. This type of temperature control method generally has a strong cooling effect, but the corresponding cooling system is also relatively complex. Both the cooling fluid flow channel and the reaction flow channel have a great influence on the temperature control of the PEMFC and the overall performance of the stack. The design optimization of such flow channels has always been a pressing issue in fuel cell research. Considering the existence of some extreme situations, the cold start performance of PEMFCs needs to be improved so that they can be successfully started and run stably. Overall, improving the battery's cold start performance mainly includes external and internal auxiliary start strategies. External auxiliary starting is mainly achieved through auxiliary equipment or materials, and generally requires additional equipment investment. The internal auxiliary starting method mainly depends on the optimization of the fuel cell's own structure or control strategy.

Optimizing the design of the stack material structure can improve the electrical and thermal conductivity of the stack itself. In addition to reducing the Joule heat generated by the stack itself, it can also export the internal heat generation in time, which maintains the stability of the stack temperature and improves the temperature uniformity. It has a positive effect on the performance of the fuel cell stack. Therefore, the selection and design of related material structures are particularly important.

Whether it is gas-cooled control or liquid-cooled control of the stack or the optimized design of the material structure, it has a positive effect on temperature control. In general, the temperature range of the stack is well controlled, but for temperature uniformity, there is still a temperature gradient of about $10-20^{\circ} \mathrm{C}$. At present, maintaining the uniformity of PEMFC temperature distribution can be considered from the following directions: The use of appropriate coolant and its distribution strategy, plate materials, cooling channel design, etc. These methods have been verified by experiments or simulations. It is certain that the reduction of the internal temperature gradient of the PEMFC will improve the performance of the battery, but less attention is paid to its quantitative research, and the control of temperature uniformity often requires additional investment. In this way, a comprehensive energy efficiency assessment is performed to determine the success of the temperature control method.

The key to fuel cell cold start is to adopt different strategies to assist fuel cell in maintaining their electrochemical reaction under low-temperature conditions. Both internal and 
external auxiliary start strategies can improve the cold start performance of PEMFCs. Future research studies should investigate how to quickly make the stack reach the maximum power operating state and the economics of auxiliary equipment.

Most of the current PEMFC temperature control research is aimed at its stable operating state, but it also includes transient loads. In the process of using the battery, it often faces various complex operating conditions. Take civilian PEMFC vehicles as an example. It includes the process of starting, idling, accelerating, and closing. As an important part of the fuel cell operation process, the transient load is necessary to understand the temperature change trend of the stack during the operation process and determine the temperature control strategy during the transient load, which can further improve the durability and energy efficiency of the stack.

Author Contributions: Conceptualization, Q.L. and Z.L.; methodology S.Y.; validation Q.L., Z.L. and S.Y.; formal analysis, Q.L. and C.D.; writing original draft preparation Q.L.; writing review and editing S.Y., supervision Z.L. and Y.S. All authors have read and agreed to the published version of the manuscript.

Funding: This research was funded by the National Natural Science Foundation of China [grant number 51676209 and 22008265].

Acknowledgments: The authors would like to thank the financial support from the China NSF project (NO. 51676209 and 22008265), and Collaborative Innovation Center of Building Energy Conservation and Environmental Control.

Conflicts of Interest: The authors declare no competing financial interest.

\section{References}

1. Zhang, G.; Kandlikar, S.G. A critical review of cooling techniques in proton exchange membrane fuel cell stacks. Int. J. Hydrog. Energy 2012, 37, 2412-2429. [CrossRef]

2. Dicks, A.; Rand, D. Fuel Cell Systems Explained, 3rd ed.; John Wiley \& Sons: Hoboken, NJ, USA, 2018.

3. Rath, R.; Kumar, P.; Mohanty, S.; Nayak, S.K. Recent advances, unsolved deficiencies, and future perspectives of hydrogen fuel cells in transportation and portable sectors. Int. J. Energy Res. 2019, 43, 8931-8955. [CrossRef]

4. Nguyen, H.Q.; Shabani, B. Proton exchange membrane fuel cells heat recovery opportunities for combined heating/cooling and power applications. Energy Convers. Mgmt. 2020, 204, 112328. [CrossRef]

5. Tiss, F.; Chouikh, R.; Guizani, A. Dynamic modeling of a PEM fuel cell with temperature effects. Int. J. Hydrog. Energy. 2013, 38, 8532-8541. [CrossRef]

6. Shabani, B.; Andrews, J. An experimental investigation of a PEM fuel cell to supply both heat and power in a solar-hydrogen RAPS system. Int. J. Hydrog. Energy 2011, 36, 5442-5452. [CrossRef]

7. Saygili, Y.; Eroglu, I.; Kincal, S. Model based temperature controller development for water cooled PEM fuel cell systems. Int. J. Hydrog. Energy 2015, 40, 615-622. [CrossRef]

8. Xu, J.; Zhang, C.; Fan, R.; Bao, H.; Wang, Y.; Huang, S.; Chin, C.S.; Li, C. Modelling and control of vehicle integrated thermal management system of PEM fuel cell vehicle. Energy 2020, 199, 117495. [CrossRef]

9. Penga, Ž.; Pivac, I.; Barbir, F. Experimental validation of variable temperature flow field concept for proton exchange membrane fuel cells. Int. J. Hydrog. Energy 2017, 42, 26084-26093. [CrossRef]

10. Hossain, M.S.; Shabani, B. Metal foams application to enhance cooling of open cathode polymer electrolyte membrane fuel cells. J. Power Sources 2015, 295, 275-291. [CrossRef]

11. Islam, M.; Shabani, B.; Rosengarten, G.; Andrews, J. The potential of using nanofluids in PEM fuel cell cooling systems: A review. Renew. Sustain. Energy Rev. 2015, 48, 523-539. [CrossRef]

12. Ramezanizadeh, M.; Nazari, M.A.; Ahmadi, M.H.; Chen, L. A review on the approaches applied for cooling fuel cells. Int. J. Heat Mass Transf. 2019, 139, 517-525. [CrossRef]

13. Wu, J.; Galli, S.; Lagana, I.; Pozio, A.; Monteleone, G.; Yuan, X.Z.; Martin, J.; Wang, H. An Air-cooled Proton Exchange Membrane Fuel Cell with Combined Oxidant And Coolant Flow. J. Power Sources 2009, 188, 199-204. [CrossRef]

14. Wu, H.-W. A review of recent development: Transport and performance modeling of PEM fuel cells. Appl. Energy 2016, 165, 81-106. [CrossRef]

15. Shahsavari, S.; Desouza, A.; Bahrami, M.; Kjeang, E. Thermal analysis of air-cooled PEM fuel cells. Int. J. Hydrog. Energy 2012, 37, 18261-18271. [CrossRef]

16. Macedo-Valencia, J.; Sierra, J.M.; Figueroa-Ramírez, S.J.; Díaz, S.E.; Meza, M. 3D CFD modeling of a PEM fuel cell stack. Int. J. Hydrog. Energy 2016, 41, 23425-23433. [CrossRef] 
17. Ou, K.; Yuan, W.W.; Choi, M.; Yang, S.; Kim, Y.B. Performance increase for an open-cathode PEM fuel cell with humidity and temperature control. Int. J. Hydrog. Energy 2017, 42, 29852-29862. [CrossRef]

18. Luo, L.; Jian, Q.; Huang, B.; Huang, Z.; Zhao, J.; Cao, S. Experimental study on temperature characteristics of an air-cooled proton exchange membrane fuel cell stack. Renew. Energy 2019, 143, 1067-1078. [CrossRef]

19. Jian, Q.; Huang, B.; Luo, L.; Zhao, J.; Cao, S.; Huang, Z. Experimental investigation of the thermal response of open-cathode proton exchange membrane fuel cell stack. Int. J. Hydrog. Energy 2018, 43, 13489-13500. [CrossRef]

20. Zhao, J.; Jian, Q.; Luo, L.; Huang, B.; Cao, S.; Huang, Z. Dynamic behavior study on voltage and temperature of proton exchange membrane fuel cells. Appl. Eng. 2018, 145, 343-351. [CrossRef]

21. Lee, C.Y.; Chiang, Y.C.; Weng, F.B.; Li, S.C.; Wu, P.H.; Yueh, H.I. Flexible micro temperature, voltage and current sensors for local real-time microscopic diagnosis inside high temperature proton exchange membrane fuel cell stack. Renew. Energy 2017, 108, 126-131. [CrossRef]

22. Tang, Y.-Q.; Fang, W.-Z.; Lin, H.; Tao, W.-Q. Thin film thermocouple fabrication and its application for real-time temperature measurement inside PEMFC. Int. J. Heat Mass Transf. 2019, 141, 1152-1158. [CrossRef]

23. Inman, K.; Wang, X.; Sangeorzan, B. Design of an optical thermal sensor for proton exchange membrane fuel cell temperature measurement using phosphor thermometry. J. Power Sources 2010, 195, 4753-4757. [CrossRef]

24. Siegel, C.; Mudi, G.B.; Heinzel, A. Solid-phase temperature measurements in a HTPEM fuel cell International. J. Hydrog. Energy 2011, 36, 12977-12990. [CrossRef]

25. Jung, C.Y.; Shim, H.S.; Koo, S.M.; Lee, S.H.; Yi, S.C. Investigations of the temperature distribution in proton exchange membrane fuel cells. Appl. Energy 2012, 93, 733-741. [CrossRef]

26. Ye, D.; Gauthier, E.; Benziger, J.B.; Pan, M. Bulk and contact resistances of gas diffusion layers in proton exchange membrane fuel cells. J. Power Sources 2014, 256, 449-456. [CrossRef]

27. Netwall, C.J.; Gould, B.D.; Rodgers, J.A.; Nasello, N.J.; Swider-Lyons, K.E. Decreasing contact resistance in proton-exchange membrane fuel cells with metal bipolar plates. J. Power Sources 2013, 227, 137-144. [CrossRef]

28. Wen, C.-Y.; Lin, Y.-S.; Lu, C.-H. Performance of a proton exchange membrane fuel cell stack with thermally conductive pyrolytic graphite sheets for thermal management. J. Power Sources 2009, 189, 1100-1105. [CrossRef]

29. Wen, C.-Y.; Lin, Y.-S.; Lu, C.-H.; Luo, T.-W. Thermal management of a proton exchange membrane fuel cell stack with pyrolytic graphite sheets and fans combined. Int. J Hydrog. Energy 2011, 36, 6082-6089. [CrossRef]

30. Tian, R.; Sun, J. Corrosion resistance and interfacial contact resistance of TiN coated 316L bipolar plates for proton exchange membrane fuel cell. Int. J. Hydrog. Energy 2011, 36, 6788-6794. [CrossRef]

31. Wilberforce, T.; Ijaodola, O.; Ogungbemi, E.; Khatib, F.N.; Leslie, T.; El-Hassan, Z.; Thomposon, J.; Olabi, A.G. Technical evaluation of proton exchange membrane (PEM) fuel cell performance-A review of the effects of bipolar plates coating. Renew. Sustain. Energy Rev. 2019, 113, 109286.1-109286.15. [CrossRef]

32. Jannat, S.; Rashtchi, H.; Atapour, M.; Golozar, M.A.; Elmkhah, H.; Zhiani, M. Preparation and performance of nanometric Ti/TiN multi-layer physical vapor deposited coating on 316L stainless steel as bipolar plate for proton exchange membrane fuel cells. J. Power Sources 2019, 435, 226818. [CrossRef]

33. Chanda, U.K.; Behera, A.; Roy, S.; Pati, S. Evaluation of Ni-Cr-P coatings electrodeposited on low carbon steel bipolar plates for polymer electrolyte membrane fuel cell. Int. J. Hydrog. Energy 2018, 43, 23430-23440. [CrossRef]

34. Wang, Y.; Zhang, S.; Lu, Z.; Wang, L.; Li, W. Preparation and performances of electrically conductive Nb-doped TiO_2 coatings for 316 stainless steel bipolar plates of proton-exchange membrane fuel cells. Corros. Sci. 2018, 142, 249-257. [CrossRef]

35. Wang, J.; Min, L.; Fang, F.; Zhang, W.; Wang, Y. Electrodeposition of graphene nano-thick coating for highly enhanced performance of titanium bipolar plates in fuel cells. Int. J. Hydrog. Energy 2019, 44, 16909-16917. [CrossRef]

36. Lyons, K.S.; Gould, B.D. Lightweight Titanium Metal Bipolar Plates for PEM Fuel Cells. Mater. Sci. Forum 2017, 879, 613-618. [CrossRef]

37. Zhang, D.; Duan, L.; Guo, L.; Tuan, W.H. Corrosion behavior of TiN-coated stainless steel as bipolar plate for proton exchange membrane fuel cell. Int. J. Hydrog. Energy 2010, 35, 3721-3726. [CrossRef]

38. Kwon, O.-J.; Fleury, E.; Han, S.-H. Surface properties of Ti(N, C, O) thin coating layers deposited by PA-MOCVD for bipolar plates used PEMFC. Met. Mater. Int. 2011, 17, 457-462. [CrossRef]

39. Lee, W.; Yun, E.; Lee, H.; Hong, S.W.; Kwon, S. Ultrathin effective TiN protective films prepared by plasma-enhanced atomic layer deposition for high performance metallic bipolar plates of polymer electrolyte membrane fuel cells. Appl. Surf. Sci. 2020, $519,146215$. [CrossRef]

40. Longrie, D.; Deduytsche, D.; Haemers, J.; Smet, P.F.; Driesen, K.; Detavernier, C. Thermal and plasma-enhanced atomic layer deposition of TiN using TDMAT and NH3 on particles agitated in a rotary reactor. Acs Appl. Mater. Interfaces 2014, 6, 7316-7324. [CrossRef]

41. Lee, W.; Yun, E.; Lee, H.; Hong, S.W.; Kwon, S. Dataset for TiN thin films prepared by plasma-enhanced atomic layer deposition using tetrakis (dimethylamino) titanium (TDMAT) and titanium tetrachloride (TiCl4) precursor. Data Brief 2020, 31, 105777, in press. [CrossRef]

42. Padula, N.A. Development of Multilayer Titanium Nitride-Based Coatings as Corrosion Resistant Films for Stainless Steel Bipolar Plates in PEM Fuel Cells; State University of New York at Albany: Albany, NY, USA, 2017. 
43. Zhang, H.; Lin, G.; Hou, M.; Hu, L.; Han, Z.; Fu, Y.; Shao, Z.; Yi, B. CrN/Cr multilayer coating on 316L stainless steel as bipolar plates for proton exchange membrane fuel cells. J. Power Sources 2012, 198, 176-181. [CrossRef]

44. Li, R.; Cai, Y.; Wippermann, K.; Lehnert, W. CrN/Cr coating-modified 316L stainless steel bipolar plates for high temperature polymer electrolyte fuel cells. J. Power Sources 2019, 434, 226718. [CrossRef]

45. Kim, L.H.; Kim, K.; Park, S.; Jeong, Y.J.; Kim, H.; Chung, D.S.; Kim, S.H.; Park, C.E. Al2O3/TiO2 nanolaminate thin film encapsulation for organic thin film transistors via plasma-enhanced atomic layer deposition. Acs Appl. Mater. Interfaces 2014, 6, 6731-6738. [CrossRef]

46. Abdulagatov, A.I.; Yan, Y.; Cooper, J.R.; Zhang, Y.; Gibbs, Z.M.; Cavanagh, A.S.; Yang, R.G.; Lee, Y.C.; George, S.M. Al ${ }_{2} \mathrm{O}_{3}$ and $\mathrm{TiO}_{2}$ atomic layer deposition on copper for water corrosion resistance. Acs Appl. Mater. Interfaces 2011, 3, 4593-4601. [CrossRef]

47. Yi, P.; Zhang, D.; Qiu, D.; Peng, L.; Lai, X. Carbon-based coatings for metallic bipolar plates used in proton exchange membrane fuel cells. Int. J. Hydrog. Energy 2019, 44, 6813-6843. [CrossRef]

48. Wang, L.; Li, L.; Liu, H.; Wang, S.; Fang, H.; Gao, H.; Gao, K.; Sun, J.; Yan, J. Polylaminate TaN/Ta coating modified ferritic stainless steel bipolar plate for high temperature proton exchange membrane fuel cell. J. Power Sources 2018, 399, 343-349. [CrossRef]

49. Mendizabal, L.; Oedegaard, A.; Kongstein, O.E.; Lædre, S.; Walmsley, J.; Barriga, J.; Gonzalez, J.J. TaNx coatings deposited by HPPMS on SS316L bipolar plates for polymer electrolyte membrane fuel cells: Correlation between corrosion current, contact resistance and barrier oxide film formation. Int. J. Hydrog. Energy 2017, 42, 3259-3270. [CrossRef]

50. Rajaei, V.; Rashtchi, H.; Raeissi, K.; Shamanian, M. The study of Ni-based nano-crystalline and amorphous alloy coatings on AISI 304 stainless steel for PEM fuel cell bipolar plate application. Int. J. Hydrog. Energy 2017, 42, 14264-14278. [CrossRef]

51. Taherian, R. A review of composite and metallic bipolar plates in proton exchange membrane fuel cell: Materials, fabrication, and material selection. J. Power Sources 2014, 265, 370-390. [CrossRef]

52. Yeetsorn, R.; Fowler, M.W.; Tzoganakis, C. A review of thermoplastic composites for bipolar plate materials in PEM fuel cells. In Nanocomposites with Unique Properties and Applications in Medicine and Industry; IntechOpen: London, UK, 2011.

53. Mohd Radzuan, N.A.; Sulong, A.B.; Hui, D.; Verma, A. Electrical Conductivity Performance of Predicted Modified Fibre Contact Model for Multi-Filler Polymer Composite. Polymers 2019, 11, 1425. [CrossRef]

54. Naji, A.; Krause, B.; Pötschke, P.; Ameli, A. Hybrid conductive filler/polycarbonate composites with enhanced electrical and thermal conductivities for bipolar plate applications. Polym. Compos. 2019, 40, 3189-3198. [CrossRef]

55. Lim, J.W.; Kim, M.; Lee, D.G. Conductive particles embedded carbon composite bipolar plates for proton exchange membrane fuel cells. Compos. Struct. 2014, 108, 757-766. [CrossRef]

56. Lim, J.W.; Kim, M.; Yu, Y.H. Development of carbon/PEEK composite bipolar plates with nano-conductive particles for HighTemperature PEM fuel cells (HT-PEMFCs). Compos. Struct. 2014, 118, 519-527. [CrossRef]

57. Syahrial, A.Z.; Indriyana, B.; Albar, M.E.; Rohman, S. Role of Multiwall Carbon Nano Tubes (MWCNT) on Electrical Conductivity of Polymer Composite as Alternative Materials for Bipolar Plate Fuel Cell. Mater. Sci. Forum 2013, 737, $183-190$.

58. Banerjee, S.; Pattnayek, S.; Kumar, R.; Kar, K.K. Impact of Graphite on Thermomechanical, Mechanical, Thermal, Electrical Properties, and Thermal Conductivity of HDPE/Copper Composites. Fuel Cells 2020, 20, 116-130. [CrossRef]

59. Park, H.; Woo, J.S.; Park, S. Poly (phenylene sulfide)-graphite composites for bipolar plates with preferred morphological orientation. Korean J. Chem. Eng. 2019, 36, 2133-2142. [CrossRef]

60. Radzuan, N.A.M.; Sulong, A.B.; Somalu, M.R.; Abdullah, A.T.; Husaini, T.; Rosli, R.E.; Majlana, E.H.; Rosli, M.I. Fibre orientation effect on polypropylene/milled carbon fiber composites in the presence of carbon nanotubes or graphene as a secondary filler: Application on PEM fuel cell bipolar plate. Int. J. Hydrog. Energy 2019, 44, 30618-30626. [CrossRef]

61. Park, H.; Woo, J.S.; Kim, S.H.; Park, K.S.; Park, S.H.; Park, S.Y. High-Performance Fluorinated Ethylene-Propylene/Graphite Composites Interconnected with Single-Walled Carbon Nanotubes. Macromol. Res. 2019, 27, 1161-1166. [CrossRef]

62. Qiu, D.; Yi, P.; Peng, L.; Lai, X. Assembly design of proton exchange membrane fuel cell stack with stamped metallic bipolar plates. Int. J. Hydrog. Energ. 2015, 40, 11559-11568. [CrossRef]

63. Meidanshahi, V.; Karimi, G. Dynamic modeling, optimization and control of power density in a PEM fuel cell. Appl. Energ. 2012, 93, 98-105. [CrossRef]

64. Mason, T.J.; Millichamp, J.; Neville, T.P.; El-kharouf, A.; Pollet, B.G.; Brett, D.J.L. Effect of clamping pressure on ohmic resistance and compression of gas diffusion layers for polymer electrolyte fuel cells. J. Power Sources 2012, 219, 52-59. [CrossRef]

65. Zamel, N.; Li, X.; Shen, J. Numerical estimation of the effective electrical conductivity in carbon paper diffusion media. Appl. Energ. 2012, 93, 39-44. [CrossRef]

66. Qiu, D.; Janßen, H.; Peng, L.; Irmscher, P.; Lai, X.; Lehnert, W. Electrical resistance and microstructure of typical gas diffusion layers for proton exchange membrane fuel cell under compression. Appl. Energy 2018, 231, 127-137. [CrossRef]

67. Lin, J.H.; Chen, W.H.; Su, Y.J.; Ko, T.H. Effect of gas diffusion layer compression on the performance in a proton exchange membrane fuel cell. Fuel 2008, 87, 2420-2424. [CrossRef]

68. Ito, H.; Heo, Y.; Ishida, M.; Nakano, A.; Someya, S.; Munakata, T. Application of a self-supporting microporous layer to gas diffusion layers of proton exchange membrane fuel cells. J. Power Sources 2017, 342, 393-404. [CrossRef]

69. Hasanpour, S.; Ahadi, M.; Bahrami, M.; Djilali, N.; Akbari, M. Woven gas diffusion layers for polymer electrolyte membrane fuel cells: Liquid water transport and conductivity trade-offs. J. Power Sources 2018, 403, 192-198. [CrossRef] 
70. Kong, I.M.; Choi, J.W.; Kim, S.I.; Lee, E.S.; Kim, M.S. Experimental study on the self-humidification effect in proton exchange membrane fuel cells containing double gas diffusion backing layer. Appl. Energ. 2015, 145, 345-353. [CrossRef]

71. Zenyuk, I.V.; Parkinson, D.Y.; Connolly, L.G.; Weber, A.Z. Gas-diffusion-layer structural properties under compression via X-ray tomography. J. Power Sources 2016, 328, 364-376. [CrossRef]

72. Yang., S.Y.; Guo., Q.S.; Li., L.J. Research progress of the sulfonated poly (ether ether ketone) s membranes for proton exchange membrane fuel cell. Chem. Ind. Eng. Prog. 2016, 35, 2850-2860.

73. Yan, X.; Zheng, W.; Ruan, X.; Pan, Y.; Wu, X.; He, G. The control and optimization of macro/micro-structure of ion conductive membranes for energy conversion and storage. Chin. J. Chem. Eng. 2016, 24, 558-571. [CrossRef]

74. Danilczuk, M.; Perkowski, A.J.; Schlick, S. Ranking the stability of perfluorinated membranes used in fuel cells to attack by hydroxyl radicals and the effect of Ce (III). A competitive kinetics approach based on spintrapping ESR. Macromolecules 2010, 43, 73352-73358. [CrossRef]

75. Bose, S.; Kuila, T.; Nguyen, T.X.H.; Kim, N.H.; Lau, K.T.; Lee, J.H. Polymer mem-branes for high temperature proton exchange mem-brane fuel cell: Recent advances and challenges. Prog. Polym. Sci. 2011, 36, 6813-6843. [CrossRef]

76. Song, T.; Chen, Z.; He, H.; Liu, Y.; Liu, Y.; Ramakrishna, S. Orthogonal design study on factors affecting the diameter of perfiuorinated sulfonic acidnanofibers during electrospinning. J. Appl. Polym. Sci. 2015, 132, 41755. [CrossRef]

77. Wang, L.; Zhu, G.M.; Li, J.Q.; Gao, C.M. Synthesis and characterization of partially fluorinated poly(fluorenyl ether ketone)s with different degrees of sulfonation as proton exchange membranes. Polymer Bulletin 2011, 66, 925-937. [CrossRef]

78. Chun, J.H.; Kim, S.G.; Lee, J.Y.; Hyeon, D.H.; Chun, B.H.; Kim, S.H.; Park, K.T. Crosslinked sulfonated poly(arylene ether sulfone)/silica hybrid membranes for high temperature proton exchange membrane fuel cells. Renew. Energy 2013, 51, 22-28. [CrossRef]

79. Hazarika, M.; Jana, T. Novel proton exchange membrane for fuel cell developed from blends of polybenzimidazole with fluorinated polymer. Eur. Polym. J. 2013, 49, 1564-1576. [CrossRef]

80. Kusoglu, A.; Weber, A.Z. New insights into perfluorinated sulfonic-acid ionomers. Chem. Rev. 2017, 117, 987-1104. [CrossRef] [PubMed]

81. Ozden, A.; Ercelik, M.; Devrim, Y.; Colpan, C.O.; Hamdullahpur, F. Evaluation of sulfonated polysulfone/zirconium hydrogen phosphate composite membranes for direct methanol fuel cells. Electrochim. Acta 2017, 256, 196-210. [CrossRef]

82. Xie, H.; Tao, D.; Xiang, X.; Ou, Y.; Bai, X.; Wang, L. Synthesis and properties of highly branched star-shaped sulfonated block poly (arylene ether)s as proton exchange membranes. J. Membr. Sci. 2015, 473, 226-236. [CrossRef]

83. Sun, H.; Tang, B.; Wu, P. Two-dimensional zeolitic imidazolate framework/carbon nanotube hybrid networks modified proton exchange membranes for improving transport properties. Acs Appl. Mater. Interfaces 2017, 9, 35075-35085. [CrossRef]

84. Yao, Z.; Zhang, Z.; Hu, M.; Hou, J.; Wu, L.; Xu, T. Perylene-based sulfonated aliphatic polyimides for fuel cell applications: Performance enhancement by stacking of polymer chains. J. Membr. Sci. 2018, 547, 43-50. [CrossRef]

85. Matian, M.; Marquis, A.; Brandon, N. Model based design and test of cooling plates for an air-cooled polymer electrolyte fuel cell stack. Int. J. Hydrog. Energy 2011, 36, 6051-6066. [CrossRef]

86. Guo, H.; Wang, M.H.; Liu, J.X.; Nie, Z.H.; Ye, F.; Ma, C.F. Temperature distribution on anodic surface of membrane electrode assembly in proton exchange membrane fuel cell with interdigitated flow bed. J. Power Sources 2015, 273, 775-783. [CrossRef]

87. Guo, H.; Wang, M.H.; Ye, F.; Ma, C.F. Experimental study of temperature distribution on anodic surface of MEA inside a PEMFC with parallel channels flow bed. Int. J. Hydrog. Energy 2012, 37, 13155-13160. [CrossRef]

88. Li, S.A.; Yuan, J.L.; Xie, G.N.; Sunden, B. Numerical investigation of transport phenomena in high temperature proton exchange membrane fuel cells with different flow field designs. Numer. Heat Transf. A 2017, 72, 807-820. [CrossRef]

89. Han, C.L.; Chen, Z.Q. Numerical simulation for the effect of vaporization intensity in membrane on the performance of PEM fuel cell. Numer. Heat Transf. A 2018, 73, 177-194. [CrossRef]

90. Singdeo, D.; Dey, T.; Gaikwad, S.; Andreasen, S.J.; Ghosh, P.C. A new modified serpentine flow field for application in high temperature polymer electrolyte fuel cell. Appl. Energy 2017, 195, 13-22. [CrossRef]

91. Li, S.A.; Sunden, B. Three-dimensional modeling and investigation of high temperature proton exchange membrane fuel cells with metal foams as flow distributor. Int. J. Hydrog. Energy 2017, 42, 27323-27333. [CrossRef]

92. Afshari, E.; Mosharaf-Dehkordi, M.; Rajabian, H. An investigation of the PEM fuel cells performance with partially restricted cathode flow channels and metal foam as a flow distributor. Energy 2017, 118, 705-715. [CrossRef]

93. Tseng, C.J.; Heush, Y.J.; Chiang, C.J.; Lee, Y.H.; Lee, K.R. Application of metal foams to high temperature PEM fuel cells. Int. J. Hydrog. Energy 2016, 41, 16196-16204. [CrossRef]

94. Baik, K.D.; Lee, E.H.; Yoon, H.; Kim, J.Y.; Yang, S.H. Effect of multi-hole flow field structure on the performance of H_2/O_2 polymer electrolyte membrane fuel cells. Int. J. Hydrog. Energy 2019, 44, 25894-25904. [CrossRef]

95. Li, S.; Sundén, B. Numerical study on thermal performance of non-uniform flow channel designs for cooling plates of PEM fuel cells. Numeric. Heat Transf. Part A Appl. 2018, 74, 917-930. [CrossRef]

96. Afshari, E.; Ziaei-Rad, M.; Dehkordi, M.M. Numerical investigation on a novel zigzag-shaped flow channel design for cooling plates of PEM fuel cells. J. Energy Inst. 2017, 90, 752-763. [CrossRef]

97. Yu, S.H.; Sohn, S.; Nam, J.H.; Kim, C. Numerical study to examine the performance of multi-pass serpentine flow-fields for cooling plates in polymer electrolyte membrane fuel cells. J. Power Sources 2009, 194, 697-703. [CrossRef] 
98. Kurnia, J.C.; Sasmito, A.P.; Mujumdar, A.S. Numerical investigation of laminar heat transfer performance of various cooling channel designs. Appl. Therm. Eng. 2011, 31, 1293-1304. [CrossRef]

99. Ravishankar, S.; Prakash, K.A. Numerical studies on thermal performance of novel cooling plate designs in polymer electrolyte membrane fuel cell stacks. Appl. Therm. Eng. 2014, 66, 239-251. [CrossRef]

100. Afshari, E.; Ziaei-Rad, M.; Shariati, Z. A study on using metal foam as coolant fluid distributor in the polymer electrolyte membrane fuel cell. Int. J. Hydrog. Energy 2016, 41, 1902-1912. [CrossRef]

101. Noorkami, M.; Robinson, J.B.; Meyer, Q.; Obeisun, O.A.; Fraga, E.S.; Reisch, T.; Shearing, P.R.; Brett, D.J. Effect of temperature uncertainty on polymer electrolyte fuel cell performance. Int. J. Hydrog. Energy 2014, 39, 1439-1448. [CrossRef]

102. De las Heras, A.; Vivas, F.J.; Segura, F.; Redondo, M.J.; Andújar, J.M. Air-cooled fuel cells: Keys to design and build the oxidant/cooling system. Renew. Energy 2018, 125, 1-20. [CrossRef]

103. Oro, M.V.; Bazzo, E. Flat heat pipes for potential application in fuel cell cooling. Appl. Eng. 2015, 90, 848-857. [CrossRef]

104. Tolj, I.; Penga, Ž.; Vukičević, D.; Barbir, F. Thermal management of edge-cooled $1 \mathrm{~kW}$ portable proton exchange membrane fuel cell stack. Appl. Energy 2020, 257, 114038. [CrossRef]

105. Sasmito, A.P.; Shamim, T.; Birgersson, E.; Mujumdar, A.S. Computational Study of Edge Cooling for Open-Cathode Polymer Electrolyte Fuel Cell Stacks. J. Fuel Cell Sci. Technol. 2012, 9, 1-8. [CrossRef]

106. Han, C.; Chen, Z. Study on electrochemical and mass transfer coupling characteristics of proton exchange membrane (PEM) fuel cell based on a fin-like electrode surface. Int. J. Hydrog. Energy 2018, 43, 8026-8039. [CrossRef]

107. Sasmito, A.P.; Shamim, T.; Birgersson, E. Numerical Investigation of Water and Temperature Distributions for Open-Cathode Polymer Electrolyte Fuel Cell Stack with Edge Cooling. J. Fuel Cell Sci. Technol. 2013, 10, 061003. [CrossRef]

108. Mohamed, W.A.N.W.; Atan, R. Experimental thermal analysis on air cooling for closed-cathode Polymer Electrolyte Membrane fuel cells. Int. J. Hydrog. Energy 2015, 40, 10605-10626. [CrossRef]

109. Meyer, Q.; Himeur, A.; Ashton, S.; Curnick, O.; Clague, R.; Reisch, T.; Adcock, P.; Shearing, P.R.; Brett, D.J.L. System-level electro-thermal optimisation of air-cooled open-cathode polymer electrolyte fuel cells: Air blower parasitic load and schemes for dynamic operation. Int. J. Hydrog. Energy 2015, 40, 16760-16766. [CrossRef]

110. Strahl, S.; Costa-Castello, R. Model-based analysis for the thermal management of open-cathode proton exchange membrane fuel cell systems concerning efficiency and stability. J. Process Control. 2016, 47, 201-212. [CrossRef]

111. Rosli, R.E.; Sulong, A.B.; Daud, W.R.W.; Zulkifley, M.A.; Husaini, T.; Rosli, M.I.; Majlan, E.H.; Haque, M.A. A review of hightemperature proton exchange membrane fuel cell (HT-PEMFC) system. Int. J. Hydrog. Energy 2017, 42, 9293-9314. [CrossRef]

112. Sasmito, A.; Lum, K.; Birgersson, E.; Mujumdar, A. Computational study of forced air-convection in open-cathode polymer electrolyte fuel cell stacks. J. Power Sources 2010, 195, 5550-5563. [CrossRef]

113. Bvumbe, T.J.; Bujlo, P.; Tolj, I.; Mouton, K.; Swart, G.; Pasupathi, S.; Pollet, B.G. Review on management, mechanisms and modelling of thermal processes in PEMFC. Hydrog. Fuel Cells 2016, 1, 1-20. [CrossRef]

114. Yuan, W.W.; Ou, K.; Kim, Y.B. Thermal management for an air coolant system of a proton exchange membrane fuel cell using heat distribution optimization. Appl. Eng. 2020, 167, 114715. [CrossRef]

115. Cheng, S.; Fang, C.; Xu, L.; Li, J.; Ouyang, M. Model-based temperature regulation of a pem fuel cell system on a city bus. Int. J. Hydrog. Energy 2015, 40, 13566-13575. [CrossRef]

116. Clement, J.; Wang, X. Experimental investigation of pulsating heat pipe performance with regard to fuel cell cooling application. Appl. Eng. 2013, 50, 268-274. [CrossRef]

117. Islam, M.R.; Shabani, B.; Rosengarten, G. Electrical and Thermal Conductivities of 50/50 Water-ethylene Glycol Based TiO2 Nanofluids to be Used as Coolants in PEM. Fuel Cells Energy Procedia 2017, 110, 101-108. [CrossRef]

118. Sheikholeslami, M.; Ganji, D.D. Numerical modeling of magnetohydrodynamic CuO-Water transportation inside a porous cavity considering shape factor effect. Colloids Surf. A Phys. Eng. Asp. 2017, 529, 705-714. [CrossRef]

119. Snoussi, L.; Ouerfelli, N.; Chesneau, X.; Chamkha, A.J.; Belgacem, F.B.M.; Guizani, A. Natural convection heat transfer in a nanofluid filled U-shaped enclosures: Numerical investigations. Heat Transf. Eng. 2017, 39, 1-11. [CrossRef]

120. Hajmohammadi, M.R.; Tork, M.H.H.M.A. Effects of the magnetic field on the cylindrical Couette flow and heat transfer of a nanofluid. Phys. A Stat. Mech. Appl. 2019, 523, 234-245. [CrossRef]

121. Haridas, D.; Rajput, N.S.; Srivastava, A. Interferometric study of heat transfer characteristics of Al2O3 and SiO2-based dilute nanofluids under simultaneously developing flow regime in compact channels. Int. J. Heat Mass Transf. 2015, 88, 713-727. [CrossRef]

122. Kumar, N.; Sonawane, S.S. Experimental study of thermal conductivity and convective heat transfer enhancement using CuO and TiO2 nanoparticles. Int. J. Heat Mass Transf. 2016, 76, 98-107. [CrossRef]

123. Islam, M.R.; Shabani, B.; Rosengarten, G. Nanofluids to improve the performance of PEM fuel cell cooling systems: A theoretical approach. Appl. Energy 2016, 178, 660-671. [CrossRef]

124. Zakaria, I.A.; Mohamed, W.A.N.W.; Zailan, M.B.; Azmi, W.H. Experimental analysis of SiO2-Distilled water nanofluids in a Polymer Electrolyte Membrane fuel cell parallel channel cooling plate. Int. J. Hydrog. Energy 2019, 44, 25850-25862. [CrossRef]

125. Islam, R.; Shabani, B. Prediction of electrical conductivity of TiO 2 water and ethylene glycol-based nanofluids for cooling application in low temperature PEM fuel cells. Energy Procedia 2019, 160, 550-557. [CrossRef] 
126. Zakaria, I.; Azmi, W.H.; Mohamed, W.A.N.W.; Mamat, R.; Najafi, G. Experimental investigation of thermal conductivity and electrical conductivity of $\mathrm{Al} 2 \mathrm{O} 3$ nanofluid in water-ethylene glycol mixture for proton exchange membrane fuel cell application. Int. Commun. Heat Mass Transf. 2015, 61, 61-68. [CrossRef]

127. Islam, R.; Shabani, B.; Andrews, J.; Rosengarten, G. Experimental investigation of using ZnO nanofluids as coolants in a PEM fuel cell. Int. J. Hydrog. Energy 2017, 42, 19272-19286. [CrossRef]

128. Fly, A.; Thring, R.H. A comparison of evaporative and liquid cooling methods for fuel cell vehicles. Int. J. Hydrog. Energy 2016, 41, 14217-14229. [CrossRef]

129. Song, T.-W.; Choi, K.-H.; Kim, J.-R.; Jung, S.Y. Pumpless thermal management of water-cooled high-temperature proton exchange membrane fuel cells. J. Power Sources 2011, 196, 4671-4679. [CrossRef]

130. Ramezanizadeh, M.; Nazari, M.A.; Ahmadi, M.H.; Chau, K. Experimental and numerical analysis of a nanofluidic thermosyphon heat exchanger. Eng. Appl. Comput. Fluid Mech. 2019, 13, 40-47. [CrossRef]

131. Alizadeh, H.; Ghasempour, R.; Shafii, M.B.; Ahmadi, M.H.; Yan, W.-M.; Nazari, M.A. Numerical simulation of PV cooling by using single turn pulsating heat pipe. Int. J. Heat Mass Transf. 2018, 127, 203-208. [CrossRef]

132. Shirzadi, N.; Roshandel, R.; Shafii, M.B. Integration of miniature heat pipes into a proton exchange membrane fuel cell for cooling applications. Heat Transf. Eng. 2017, 38, 1595-1605. [CrossRef]

133. Hwang, S.H.; Kim, M.S. An experimental study on the cathode humidification and evaporative cooling of polymer electrolyte membrane fuel cells using direct water injection method at high current densities. Appl. Eng. 2016, 99, 635-644. [CrossRef]

134. Schultze, M.; Horn, J. A control oriented simulation model of an evaporation cooled polymer electrolyte membrane fuel cell system. In Proceedings of the 18th International Federation of Automatic Control World Congress, Milan, Italy, 28 August-2 September 2011; pp. 14790-14795.

135. Fly, A.; Thring, R.H. Temperature regulation in an evaporatively cooled proton exchange membrane fuel cell stack. Int. J. Hydrog. Energy 2015, 40, 11976-11982. [CrossRef]

136. Luo, Y.; Jiao, K. Cold start of proton exchange membrane fuel cell. Prog. Energy Combust. 2018, 64, 29-61. [CrossRef]

137. Tajiri, K.; Wang, C.Y. Ishothermal Cold Start of Polymer Electrolyte Fuel Cells. J. Electrochem. Soc. 2006, 154, B147-152. [CrossRef]

138. Yamada, K.; Suzuki, K.; Tabe, Y.; Chikahisa, T. Analysis of ice distribution in cathode catalyst layer and shutdown mechanism at PEFC cold start. Ecs Trans. 2013, 58, 463-471. [CrossRef]

139. Amamou, A.; Kelouwani, S.; Boulon, L.; Agbossou, K. A comprehensive review of solutions and strategies for cold start of automotive proton exchange membrane fuel cells. Ieee Access 2016, 4, 4989-5002. [CrossRef]

140. Tabe, Y.; Saito, M.; Fukui, K.; Chikahisa, T. Cold start characteristics and freezing mechanism dependence on start-up temperature in a polymer electrolyte membrane fuel cell. J. Power Sources 2012, 208, 366-373. [CrossRef]

141. Pan, W.; Li, P. Thermal stability analysis of cold start processes in PEM fuel cells. Appl. Energy 2020, 261, 114430. [CrossRef]

142. Dursch, T.J.; Trigub, G.J.; Lujan, R.; Liu, J.F.; Mukundan, R.; Radke, C.J.; Weber, A.Z. Ice-crystallization kinetics in the catalyst layer of a proton-exchange-membrane fuel cell. J. Electrochem. Soc. 2014, 16, F199-F207. [CrossRef]

143. Huo, S.; Jiao, K.; Park, J.W. On the water transport behavior and phase transition mechanisms in cold start operation of PEM fuel cell. Appl. Energy 2019, 233-234, 776-788. [CrossRef]

144. Ko, J.; Kim, W.-G.; Lim, Y.-D.; Ju, H. Improving the cold-start capability of polymer electrolyte fuel cells (PEFCs) by using a dual-function micro-porous layer (MPL): Numerical simulations. Int. J. Hydrog. Energy 2013, 38, 652-659. [CrossRef]

145. Ko, J.; Ju, H. Effects of cathode catalyst layer design parameters on cold start behavior of polymer electrolyte fuel cells (PEFCs). Int. J. Hydrog. Energy 2013, 38, 682-691. [CrossRef]

146. Xie, X.; Wang, R.; Jiao, K.; Zhang, G.; Zhou, J.; Du, Q. Investigation of the effect of micro-porous layer on PEM fuel cell cold start operation. Renew. Energy 2018, 117, 125-134. [CrossRef]

147. Yang, Z.; Du, Q.; Huo, S.; Jiao, K. Effect of membrane electrode assembly design on the cold start process of proton exchange membrane fuel cells. Int. J. Hydrog. Energy 2017, 42, 25372-25387. [CrossRef]

148. Xie, X.; Zhang, G.; Zhou, J.; Jiao, K. Experimental and theoretical analysis of ionomer/carbon ratio effect on PEM fuel cell cold start operation. Int. J. Hydrog. Energy 2017, 42, 12521-12530. [CrossRef]

149. Kim, Y.S.; Kim, S.I.; Lee, N.W.; Kim, M.S. Study on a purge method using pressure reduction for effective water removal in polymer electrolyte membrane fuel cells. Int. J. Hydrog. Energy 2015, 40, 9473-9484. [CrossRef]

150. Wei, L.; Dafalla, A.M.; Jiang, F. Effects of reactants/coolant non-uniform inflow on the cold start performance of PEMFC stack. Int. J. Hydrog. Energy 2020, 45, 13469-13482. [CrossRef]

151. Gwak, G.; Ko, J.; Ju, H. Numerical investigation of cold-start behavior of polymer-electrolyte fuel-cells from subzero to normal operating temperatures-effects of cell boundary and operating conditions. Int. J. Hydrog. Energy 2014, 39, 21927-21937. [CrossRef]

152. Dafalla, A.M.; Wei, L.; Liao, Z.; Jiang, F. Numerical Investigation of Clamping System Effects on the Cold Start Polymer Electrolyte Fuel Cell Performance. In Proceedings of the International Heat Transfer Conference 16, Beijing, China, 10-15 August 2018.

153. Dafalla, A.M.; Wei, L.; Liao, Z.H.; Jiang, F.M. Effects of Clamping Pressure on Cold Start Behavior of Polymer Electrolyte Fuel Cells. Fuel Cells 2019, 19, 221-230. [CrossRef]

154. Xie, X.; Zhu, M.; Wu, S.; Tongsh, C.; Sun, X.; Wang, B.; Park, J.W.; Jiao, K. Investigation of mechanical vibration effect on proton exchange membrane fuel cell cold start. Int. J. Hydrog. Energy 2020, 45, 14528-14538. [CrossRef]

155. Yamada, K. Fuel cell device and related control method. U.S. Patent 7537850, 26 May 2009.

156. Harris, D.I. Rapid light-off catalytic combustor for fuel cell vehicle. U.S. Patent 7960064, 14 June 2011. 
157. Knorr, F.; Sanchez, D.G.; Schirmer, J.; Gazdzicki, P.; Friedrich, K.A. Methanol as antifreeze agent for cold start of automotive polymer electrolyte membrane fuel cells. Appl. Energy 2019, 238, 1-10. [CrossRef]

158. Gwak, G.; Ju, H. A rapid start-up strategy for polymer electrolyte fuel cells at subzero temperatures based on control of the operating current density. Int. J. Hydrog. Energy 2015, 40, 11989-11997. [CrossRef]

159. Amamou, A.; Kandidayeni, M.; Boulon, L.; Kelouwani, S. Real time adaptive efficient cold start strategy for proton exchange membrane fuel cells. Appl. Energy 2018, 216, 21-30. [CrossRef]

160. Reddy, E.H.; Jayanti, S. Thermal management strategies for a $1 \mathrm{k}$ We stack of a high temperature proton exchange membrane fuel cell. Appl. Eng. 2012, 48, 465-475.

161. Jiao, K.; Alaefour, I.E.; Karimi, G.; Li, X. Simultaneous measurement of current and temperature distributions in a proton exchange membrane fuel cell during cold start processes. Electrochim. Acta 2011, 56, 2967-2982. [CrossRef]

162. Hasan, M.I. Numerical investigation of counter flow microchannel heat exchanger with MEPCM suspension. Appl. Therm. Eng. 2011, 31, 1068-1075. [CrossRef]

163. Sasmito, A.P.; Shamim, T.; Mujumdar, A.S. Passive thermal management for PEM fuel cell stack under cold weather condition using phase change materials (PCM). Appl. Therm. Eng. 2013, 58, 615-625. [CrossRef]

164. Li, L.; Wang, S. Cold-start method for proton-exchange membrane fuel cells based on locally heating the cathode. Appl. Energy 2019, 254, 113716. [CrossRef]

165. Zhigang, Z.; Chong, Y.; Zhangrong, H.; Hui, W.; Sui, P.C.; Ned, D.; Mu, P. Experimental study on different preheating methods for the cold-start of PEMFC stacks. Energy 2018, 162, 1029-1040.

166. Zhou, Y.; Luo, Y.; Yu, S.; Jiao, K. Modeling of cold start processes and performance optimization for proton exchange membrane fuel cell stacks. J. Power Sources 2014, 247, 738-748. [CrossRef] 